International Journal of Medical Sciences

ISSN 1449-1907 www.medsci.org 2005 2(1):24-29

(C)2005 Ivyspring International Publisher. All rights reserved

\title{
Review $\quad$ Advances in immunomodulating therapy of HBV infection
}

Received: 2004.10 .01

Accepted: 2005.01 .01

Published:2005.01.05

Abstract

Key words

Author

biography

Corresponding address
Chee-Kin Hui ${ }^{1}$, George KK Lau ${ }^{2}$

1. MRC Cancer Cell Unit, University of Cambridge, Cambridge, UK.

2. Department of Medicine, University of Hong Kong, Hong Kong

Patients with chronic hepatitis B virus (HBV) infection have a higher risk of developing liver cirrhosis and hepatocellular carcinoma. Interferon- $\alpha$, lamivudine and adefovir dipivoxil are the three approved treatment for chronic HBV infection and offers the only means of preventing the development of these complications. However, the efficacy of these agents, in terms of loss of Hepatitis B e antigen with or without seroconversion to Hepatitis B e antibody, normalization of serum alanine transaminase levels, loss of serum HBV DNA, and improvement in liver histology can only be achieved in 20-30\% of those treated. Long-term treatment with either lamivudine or adefovir dipivoxil can result in the development of drug resistant mutants leading to an increased length of treatment with additional nucleoside analogues. These limitations of the current antiviral therapies underline the need for alternative therapies. Specific and nonspecific immunotherapeutic strategies to restore effective virus-specific $\mathrm{T}$ cell responses in those with chronic HBV infection offers an interesting alternative approach. These immunotherapeutic therapies include the adoptive transfer of $\mathrm{HBV}$ immunity, pegylated interferon and therapeutic vaccine therapies.

immunomodulating therapy, HBV infection

George KK Lau, MD is an Assistant Dean of the Faculty of Medicine, The University of Hong Kong. His research interests include hepatitis B infection in immunosuppressed patients, design of immune-related and combination therapy for chronic hepatitis B infection. $\mathrm{He}$ has a distinguished career in research of HBV reactivation after chemotherapy. He is recognized as an international leader in clinical trials for anti-HBV treatment, with more than 150 journal publications. Currently he serves as the associate editor for Liver International and Journal of Hepatology. He is also a key member for formulating the consensus statement for HBV management for Asia-Pacific Association for the study of Liver Diseases and European Association for the study of Liver.

Chee-Kin Hui, MD is a Clinical Research Fellow at the MRC Cancer Cell Unit, University of Cambridge, Cambridge, UK. His current researches include cell signaling and transcription of hepatoma cell lines. His other researches include treatment, outcome and immunomodulatory effect of nucleoside analogues on hepatitis B virus.

Dr. George KK Lau. Room 1838, Block K, Queen Mary Hospital, 102 Pokfulam Road, Hong Kong SAR, China. E-mail.gkklau@netvigator.com Tel: 852-28553986 Fax: 852- 28190694 


\section{INTRODUCTION}

Hepatitis B virus (HBV) related hepatitis is a necroinflammatory liver disease of variable severity. Most people develop acute hepatitis which is controlled by both humoral and cellular immune responses following acute infection [1]. However, around 2-20\% of infected adults and 95\% of infected newborns in HBV-endemic areas fail to resolve the infection and subsequently become chronic carriers [2]. Persistent infection is associated with a healthy chronic carrier state in about one-third of persons and with chronic liver disease that can lead to the development of liver cirrhosis and hepatocellular carcinoma in the remaining two-thirds.

The cellular immune response contributes to the elimination of the virus but is also responsible for liver damage caused by the lytic activity of HBV-specific cytotoxic T lymphocytes (CTL) on HBV-infected hepatocytes and by production of inflammatory cytokines [3]. Chronic HBV infection is characterized by an inefficient T helper (Th) cell response to hepatitis B surface antigen (HBsAg) and by a variable Th cell response to the HBV-related antigens such as hepatitis core antigen (HBcAg), and hepatitis e antigen ( $\mathrm{HBeAg}$ ). Increased $\mathrm{HBcAg} / \mathrm{HBeAg}$-specific Th cell responses are observed in persons with self-limited $\mathrm{HBV}$-infection, whereas the HBsAg-specific Th cell response is much less vigorous [1]. However, in a proportion of vaccine recipients who have been immunized with plasma-derived or recombinant $\mathrm{HBsAg}$, there is a strong response of the envelope-specific Th response suggesting that differences in antigen load or presentation may influence the strength of the HBsAg-specific T cell response [4-6].

Therapeutic intervention offers the only means of interrupting this progression. The ultimate goals of treatment are to achieve off-treatment sustained suppression of HBV replication and remission of liver disease. Agents currently approved for treatment of chronic HBV infection are divided into two main groups; the immunomodulator, interferon- $\alpha$ (IFN- $\alpha$ ), and the nucleoside analogues, lamivudine and adefovir dipivoxil. The immunomodulators act by promoting cytotoxic $\mathrm{T}$ cell activity for lysis of infected hepatocytes and by stimulating cytokine production for control of viral replication. Nucleoside analogues on the other hand act by suppressing HBV replication at the level of DNA synthesis, and may also enhance immune clearance of infected hepatocytes [7]. As IFN- $\alpha$ inhibit HBV replication in only $20-40 \%$ of persons with chronic HBV [8-10], while the use of nucleoside/nucleotide analogues such as lamivudine and adefovir dipivoxil is limited by the selection of resistant mutated viruses [11,12], there is a need for alternative approaches to treatment which includes specific and non-specific immunotherapeutic strategies in order to enhance or to broaden the defective $\mathrm{T}$ cell responses in chronically infected patients. These immunotherapeutic strategies are the adoptive immune transfer, new forms of immunomodulatory agents and therapeutic vaccine therapies.

\section{ADOPTIVE TRANSFER OF IMMUNITY}

In both animal and human studies, transfer of HBV immune memory from a immune donor through bone marrow transplantation (BMT) or peripheral blood lymphocytes (PBLs) has enabled seroconversion to Hepatitis B surface antibody in HBV naïve recipients [13-16]. Furthermore, clearance of HBsAg has been observed in individual patients with chronic hepatitis B after transplantation of bone marrow from HBV immune donors [17-19]. By studying the largest series of patients, who cleared HBsAg following the engraftment of an HLA-identical bone marrow from a donor with past exposure to HBV, we found that resolution of chronic HBV infection is associated with a transfer of CD4+ T lymphocyte reactivity to $\mathrm{HBcAg}$, rather than to $\mathrm{HBV}$ envelope proteins [20]. We have demonstrated that the CD4+ T cells are of donor origin and activation of the memory subset, $\mathrm{CD} 45-\mathrm{RO}+\mathrm{T}$ cells, occurs during the hepatitis flare, which precedes the seroconversion to anti-HBs. These results explain our earlier clinical observation that HBsAg clearance occurs only after adoptive transfer of naturally acquired immunity to HBV (anti-HBs and anti$\mathrm{HBc}$ positive donors) and not in patients who received marrow with a vaccine-induced immunity (anti-HBs alone) [21]. The practical implication of the present findings of successful HBsAg clearance following adoptive transfer of immunity to $\mathrm{HBcAg}$, is that therapeutic immunization of patients with chronic HBV infection should include the HBV nucleocapsid protein (or the core gene for DNA immunization) and aim to induce both $\mathrm{HBcAg}$-specific CD4+ and CD8+ T cell responses.

However, although adoptive transfer is an interesting alternative for the treatment of chronic HBV infection, it is associated with certain risks. The risks of adoptive transfer are those associated with BMT and the absence of immune control that may result in infections, veno-occlusive disease and graft-versus-host disease. Fulminant hepatitis resulting in hepatic failure has also been reported following adoptive transfer of immunity to HBV [22]. Thus, although adoptive transfer of immunity to HBV is a possible approach, it is restricted to the BMT setting and is limited by its potential serious complications.

Adoptive transfer of immunity to $\mathrm{HBV}$ has also been reported in patients after liver transplantation [23]. Spontaneous production of anti-HBs is observed in 21 of $50 \mathrm{HBsAg}+$ patients $(42 \%)$ receiving lamivudine monoprophylaxis after liver transplantation. Seroconversion to anti-HBs can be detected in a median of eight days. In those that developed anti-HBs seroconversion, a more rapid clearance of HBsAg is also observed and the predictor of anti-HBs production is an HBV-immune donor, suggesting the possibility of adoptive immunity transfer through a liver graft. The same could be observed in rats after kidney transplantation [24].

\section{IMMUNOMODULATORY TREATMENTS OF CHRONIC HEPATITIS B INFECTION}

\section{Cytokines}

Interferon-gamma, tumour necrosis factor-alpha and interleukin 1-beta has been shown to decrease the secretion of HBV DNA from HB611 cells transfected with HBV DNA in a dose dependent manner [25]. The expression of HBV mRNA is also decreased signifying that these agents can decrease the synthesis of virally encoded components of the HBV virions. The antiviral effect of these agents is postulated to be due to oxidative stress [25].

\section{Interleukin 2 (IL-2)}

Clearance of HBsAg with anti-HBs seroconversion has been demonstrated in co-infected patients with human immunodeficiency virus (HIV) [26]. However, similar results could not be reproduced when IL-2 is extended to chronic HBV patients without HIV co-infection. [27]. Further randomized trials with IL-2 versus placebo also did not demonstrate any difference between IL-2 and placebo [28,29]. A randomized trial of combination IL-2 and IFN- $\alpha 2 b$ versus IFN- $\alpha 2 b$ monotherapy in 37 
patients also did not show any effect on serum HBV DNA clearance, HBeAg seroconversion or normalization of serum alanine transaminase (ALT) levels. However, side effects are higher in the combination group [30]. Therefore, there is no strong evidence to demonstrate the effect of IL-2 on chronic HBV infection.

\section{Interleukin-12 (IL-12)}

IL-12 is a heterodimeric cytokine produced by antigen-presenting cells that have the ability to induce interferon- $\gamma$ (IFN- $\gamma$ ) secretion by $\mathrm{T}$ and natural killer cells and it can generate normal Th1 responses. As HBV-specific CTL can inhibit HBV replication in the livers of transgenic mice mediated by IFN- $\gamma$, there could be a possible therapeutic effect of IL-12 on HBV replication.

A study demonstrating this on HBV transgenic mice is conducted by Cavanaugh et al [31]. The authors are able to demonstrate a dose-dependent antiviral effect with the disappearance of HBV DNA replicative intermediates with IL-12 at doses of $100 \mathrm{ng}$ once a day for three days. At further higher doses, HBV DNA replicative forms were completely abolished. Serum HBV DNA level is also decreased by IL-12 [31].

In another study with recombinant human (rHu) IL-12 on 46 patients with chronic $\mathrm{HBV}$, positive serum HBV DNA level and elevated serum ALT level, a decrease in serum HBV DNA level could be observed at the end of treatment and at 12 weeks after the end of treatment. The decrease in serum HBV DNA level is also dose dependent; $25 \%$ with $0.50 \mu \mathrm{g} / \mathrm{kg}$ body weight (b.w.), $13 \%$ with $0.25 \mu \mathrm{g} / \mathrm{kg}$ b.w. and $7 \% 0.03 \mu \mathrm{g} / \mathrm{kg}$ b.w. HBeAg is undetectable in two patients (13.3\%) in those who received $0.25 \mu \mathrm{g} / \mathrm{kg}$ b.w. and in three patients (18.8\%) receiving $0.50 \mu \mathrm{g} / \mathrm{kg}$ b.w [32]. Although IL-12 shows early interesting efficacy on chronic HBV infection, more large randomized controlled studies are needed before it can be recommended as a standard treatment.

\section{Levamisole}

One study showing the immunomodulatory effect of levamisole in 25 chronic $\mathrm{HBV}$ patients $(16 \mathrm{HBeAg}+, 9 \mathrm{HBeAg}-)$ is conducted by Krastev et al. in 1999. A decrease in serum HBV DNA level is noted $(\mathrm{p}<0.05)$ with $\mathrm{HBeAg}$ seroconversion to Hepatitis B e antibody in three (18.8\%) HBeAg positive patients. Two patients (8.0\%) in this study cleared $\mathrm{HBsAg}$ [33].

\section{Oral Immune Regulation (HBV Envelope Proteins)}

Oral immune regulation is the induction of immunological hypo- or hyper responsiveness toward specific antigens or, towards other antigens present at the target site [34]. Per oral administration of low doses of $\mathrm{HBsAg}+$ preS1+preS2 envelope proteins can induce peripheral immune tolerance and downregulation of anti-HBV immune response has been demonstrated in a murine model [35]. Safadi et al. conducted a study on the safety and efficacy of per oral HBV envelope proteins (HBsAg+preS1+preS2) in 42 chronic HBV patients [36]. A significant decrease in serum HBV DNA level can be observed in $66.6 \%$ while histological improvement in liver necroinflammatory score can be seen in 30.0\%. Loss of HBeAg occurred in $26.3 \%$ and $21.1 \%$ had $\mathrm{HBeAg}$ to anti-HBe seroconversion. No patients had a lost of HBsAg or anti-HBs seroconversion.

\section{Thymosin $\alpha-1$}

Thymosin $\alpha-1$ is a 28 -amino acid polypeptide isolated from thymosin fraction 5. It is an immunomodulating agent and may enhance clearance of HBV. In vitro studies have shown that thymosin $\alpha-1$ can accelerate T-cell maturation and antigen recognition. It can also stimulate interferon and cytokine production and the activity of natural killer cell-mediated cytotoxicity [37,38].

Although thymosin $\alpha-1$ has fewer and milder side effects compared to IFN- $\alpha$, its clinical efficacy remains inconclusive. One study with $1.6 \mathrm{mg}$ twice weekly subcutaneous thymosin $\alpha-1$ for six months showed a response rate, defined as clearance of serum HBV DNA and HBeAg, of $40.6 \%$ vs. 9.4\% in the control group $(\mathrm{p}=0.004) 18$ months after the completion of treatment, although the response rate between the two groups are similar at the end of treatment [39]. In a meta-analysis of 353 patients from five trials, there is no statistically significant difference in the biochemical response although odds ratio for virological response at the end of treatment, six and 12 months after treatment are $0.56(0.20-1.52), 1.67(0.83-3.37)$ and $2.67(1.25-5.68)$ respectively. Interestingly, an increase in virological response over time after the discontinuation of thymosin could be observed $(\mathrm{p}=0.02)[40]$. The doses of thymosin $\alpha-1$ in this meta-analysis are $900 \mu \mathrm{g} / \mathrm{m}^{2}$ and $1.6 \mathrm{mg}$ twice weekly respectively for at least 24 weeks.

Combination of low dose lymphoblastoid interferon and thymosin $\alpha-1$ is evaluated in 15 patients. After 12 months, nine patients $(60.0 \%)$ responded to treatment, which is defined as negative serum HBV DNA level and normalization of serum ALT level. Forty percent had clearance of HBsAg [41]. The efficacy of thymosin $\alpha-1$ and IFN- $\alpha$ on HBeAg negative patients has also been shown by Saruc et al. [42]. Fifty-two HBeAg negative chronic HBV patients are nonrandomly assigned to three different groups. Group $1(\mathrm{n}=27)$ received thymosin $\alpha-1 \quad 1.6 \mathrm{mg}$ subcutaneously twice a week and IFN- $\alpha 2 \mathrm{~b} 10$ million units (MU) subcutaneously three times weekly for 26 weeks followed by IFN- $\alpha 2 b$ for an additional 26 weeks. Group 2 ( $n=10)$ received IFN$\alpha 2 b$ monotherapy for 52 weeks and Group $3(n=15)$ received IFN- $\alpha 2 b$ and lamivudine for 52 weeks followed by continuous lamivudine. A sustained response, defined as virological and biochemical response six months after completion of therapy, is seen in $74.0 \%$ in Group 1, $40.0 \%$ in Group 2 and $26.6 \%$ in Group $3(\mathrm{p}=0.036)$. At the end of the study, which is 18 months after the completion of treatment, $71.4 \%$ in Group 1, $10.0 \%$ in Group 2 and $20.0 \%$ in Group 3 had persistent sustained response ( $\mathrm{p}=0.0003$ ) [42]. The results of the meta-analysis and, that of Chien et al. and Saruc et al. suggest that thymosin $\alpha-1$ may be effective in suppressing viral replication with its effect being delayed until 12 months after the discontinuation of treatment $[40,42]$

Furthermore, combination of thymosin $\alpha-1$ and famciclovir for 26 weeks versus famciclovir monotherapy or placebo showed a stronger HBV DNA reduction in the combination group with a $15.6 \% \mathrm{HBeAg}$ seroconversion (none of the patients in the other two groups had HBeAg seroconversion) [43].

\section{Pegylated interferon alfa}

Recently, pegylated interferons have been developed with improved pharmacokinetic profiles and a more acceptable dosing regimen compared with conventional interferon (once-weekly subcutaneous injection). Clinical trials of pegylated interferons have provided encouraging results. In an early, phase II, proof-of-concept trial, peginterferon alfa-2a (40KD) proved more effective than conventional interferon alfa in all efficacy parameters assessed (loss of HBeAg, normalization of serum ALT) [44]. A later study of 266 predominantly Caucasian patients, showed that peginterferon alfa- $2 \mathrm{~b}(12 \mathrm{KD})$ plus lamivudine combination therapy was no more effective than peginterferon alfa-2b (12KD) alone [45]. Unfortunately, this study did not have a lamivudine monotherapy 
comparator arm. A new phase III study of $537 \mathrm{HBeAg}$ negative, predominantly Asian patients, comparing peginterferon alfa-2a (40KD), either alone or in combination with lamivudine for 72 weeks, showed a higher normalization of serum ALT levels and a higher rate of reduction in serum HBV DNA level less than 10,000 copies/ml in the peginterferon alfa-2a (40 KD) groups (Table 1). Loss of HBsAg with or without anti-HBs seroconversion and $\geq 2$-point reduction in HAI index are also higher in patients receiving peginterferon alfa-2a (40 KD) (Table 1) [46]. New data from a Phase III study of 814 predominantly Asian patients with peginterferon alfa-2a (40KD), either alone or in combination with lamivudine, will be available soon.

Table 1. Results of phase III study with peginterferon alfa-2a (40 kDa) on HBeAg negative Chronic HBV patients.

ALT- alanine transaminase, HBV- hepatitis B virus, HBsAg- hepatitis B surface antigen, anti-HBs- antibody to hepatitis B surface antigen, $\mathrm{HBeAg}-$ hepatitis $\mathrm{B}$ e antigen.

\section{Therapeutic Vaccine}

This is another approach that can be employed to break tolerance and stimulate T-cell immune responses in chronic HBV patients. Immunization with recombinant $\mathrm{HBsAg}$ particles

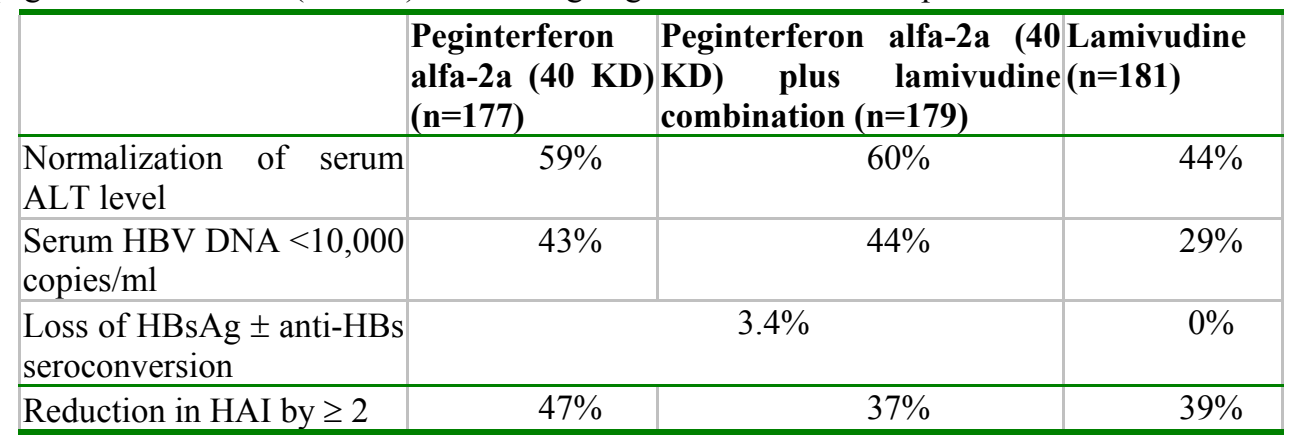

from transgenic mice expressing either HBsAg alone or replicating the virus resulted in a reduction in serum HBsAg levels, loss of $\mathrm{HBeAg}$ or even the development of anti-HBs [47,48]. Pilot clinical studies on therapeutic vaccines demonstrated that specific vaccine therapy by standard vaccination could cancel or reduce HBV replication in $50.0 \%$ of chronic HBV patients [49,50]. In a controlled study involving either GenHevac B (Pre-S2/S) [Pasteur-Merieux, n=47], Recombivax (S) [Merck, Sharp and Dhome, $n=34]$ or no vaccine $(n=37)$, seroconversion of HBeAg to anti-HBe is seen in $13.3 \%$ of vaccinees versus $3.6 \%$ of controls after six months of follow-up. After 12 months of follow-up, the HBeAg to anti-HBe seroconversion rate is $18.9 \%$ vs. $12.5 \%$ between the two groups. None of the patients had a loss of HBsAg [51]. However, in a randomized controlled study by Yalcin et al. on 71 patients with GenHevac B (Pre-S2/S), this vaccine is not significantly associated with a higher HBsAg seroconversion. Only three out of 31 patients $(9.7 \%)$ who received the vaccine cleared HBsAg with anti-HBs seroconversion. While in the control group, none of the 40 patients cleared HBsAg or developed anti-HBs seroconversion ( $p=0.079)$ [52].

Another study used adsorbed hepatitis B vaccine (MEINYU, Meiji Dairies Corporation, Tokyo) in 19 HBsAg patients with detectable serum HBV DNA (vaccinated patients, $n=13$ and control, $n=6$ ). This vaccine contains glycosylated (gp26) and nonglycosylated HBsAg spherical particles $(23 \mathrm{~nm}$ in diameter) and $4.0 \%$ preS2 protein. At the end of the study there is a significant decrease in the serum HBV DNA level in the vaccinated group compared to the control group $(p=0.03)$. However, the proportion of patients with HBsAg clearance and anti-HBs seroconversion is not available [53].

Alum-based vaccines can be used to promote the production of antibodies and a Th2 biased immune response. However, for effective therapeutic vaccination, both humoral and cytotoxic T-cell responses would be required to eradicate infected liver cells. As such, the efficacy of these vaccines can be improved by using adjuvants such as MF59 [54]. In a pilot study using MF59 as an adjuvant, anti-HBs seroconversion is achieved in 11 of 13 patients [55]. CpG DNA, a synthetic oligonucleotide that can stimulate Th1 responses, with production of IL-12 and IFN- $\gamma$ is another such adjuvant [56]. Transgenic mice study with vaccines using $\mathrm{CpG}$ DNA as an adjuvant has been shown to lead to clearance of serum HBsAg and anti-HBs seroconversion, with a downregulation of HBV mRNA production in the liver as well [56].

Another approach with therapeutic vaccines is the use of peptide based T-cell vaccines. Heathcote et al. studied the use of a lipopeptide (CY-1899) containing a T-helper epitope from tetanus toxoid and a CTL epitope from HBV core (amino acids 18-27) in 19 chronic HBV patients [57]. This CTL activity induced by the vaccine, however, is not strong enough to clear the infection. In fact, CTL activity induced by vaccination with the highest dose are 10-fold weaker than the CTL responses induced in healthy volunteers with no HBV exposure [58].

\section{DNA-Based Vaccines}

Intramuscular injection of plasmids encoding HBV antigens is another novel approach to vaccination. It can enable the expression of encoded proteins in vivo. The DNA vaccines can induce immune responses against antigens synthesized in vivo after direct introduction of DNA encoding HBV sequences. Plasmid DNA immunization can induce both humoral immune responses and CD8+ CTL responses [59,60].

Immunization with HBsAg-encoding plasmid DNA, followed by recombinant HBsAg-expressing canarypox as booster in chimpanzees with chronic HBV resulted in a 400-fold decrease in serum HBV DNA level with stable HBsAg levels [61]. Three chimpanzees with chronic $\mathrm{HBV}$ immunized with a $\mathrm{HBcAg}$-expressing retroviral vector showed seroconversion from $\mathrm{HBe} A g$ to anti$\mathrm{HBe}$ in one chimpanzee. The other two chimpanzees remained HBeAg positive with stable viral load, even though one of them had detectable $\mathrm{HBcAg}$-specific CTL responses [62].

A DNA vaccine against HBV using the PowderJect system has been conducted in healthy volunteers. This system delivers gold particles coated with plasmid DNA directly into the skin cells. This vaccine seems to be safe, well tolerated and is able to produce Th1 helper cell responses. But humoral anti-HBs responses, however, are weak [63].

Theoretically, the use of therapeutic vaccine may offer the greatest therapeutic potential. However, larger scale studies need to be conducted in order to determine not only its efficacy but also its safety and potential adverse effects in humans. A more important question that needs to be addressed is the potential adverse effects that may arise in the event of a hyper-responsiveness of the cytotoxic activity in the HBV infected liver cells. 


\section{CONCLUSION AND RESEARCH DIRECTION}

Monotherapy with nucleoside/nucleotide analogue is unlikely to cure the majority of patients with chronic hepatitis B infection. With the encouraging results being obtained from the use of pegylated interferon $\alpha$ for chronic HBV infection, it is highly likely that it will feature widely in future consensus guideline recommendations. However, it remains to be determined which patient should be treated, for how long and whether combination therapy with other immunological therapy or nucleoside/nucleotide analogues will further enhance its efficacy. A more rational form of therapy should entail the use of HBV-specific immune therapy either in the form of therapeutic vaccine or DNA vaccine. Hopefully, in the future, more research could be conducted to find an immunological curative solution for patients with chronic hepatitis B infection.

\section{Conflict of interest}

Dr. Lau has received research support from Roche Pharmaceutical and Gilead Sciences. Dr. Hui: none declared.

\section{References}

1. Chisari FV. Hepatitis B virus immunopathogenesis. Annu Rev Immunolo 1995; 13: 29-60.

2. Peters M, Vierling J, Gershwin ME, Milich D, Chisari FV, Hoofnagle JH. Immunology and the liver. Hepatology 1991; 13: $977-994$.

3. Chisari FV. Immunobiology and pathogenesis of viral hepatitis. In: Rizetto M, Purcell RH, Gerin JL, Verme G, eds. Viral hepatitis and liver disease. Turin, Italy: Edizioni Minerva Medica 1996; 405-414.

4. Celis E, Kung PC, Chang TW. Hepatitis-B related virus-reactive human T lymphocytes clones: antigen specificity and helper function for antibody synthesis. J Immunol 1984; 132: 1511-1516.

5. Celis E, Ou D, Otvos L Jr. Recognition of hepatitis B surface antigen by human T lymphocytes. Proliferative and cytotoxic responses to a major antigenic determinant defined by synthetic peptides. J Immunol 1988; 140: 1808-1815.

6. Ferrari C, Penna A, Bertoletti A, Cavalli A, Valli A, Schianchi C et al. The pre-S1 antigen of hepatitis B virus is highly immunogenic at the T cell level in man. J Clin Invest 1989; 84: 1314-1319.

7. Boni C, Bertoletti A, Penna A, Cavalli A, Pilli M, Urbani S et al. Lamivudine treatment can restore T cell responsiveness in chronic hepatitis B. J Clin Invest 1998; 102: 968-975.

8. Hoofnagle JH, di Bisceglie AM. The treatment of chronic viral hepatitis. N Eng J Med 1997; 336: 347-356.

9. Wong DKH, Cheung AM, O'Rourke K, Naylor CD, Detsky AS, Heathcote J. Effect of alpha-interferon in patients with hepatitis B e antigenpositive chronic hepatitis B: a meta-analysis. Ann Intern Med 1993; 119: 312-323.

10. Niederau K, Heintges T, Lange S, Goldmann G, Niederau CM, Mohr L et al. Long-term follow-up of HBeAg-positive patients treated with interferon-alpha for chronic hepatitis B. N Eng J Med 1996; 334: 1422-1427.

11. Lai CL, Chien RL, Leung NW, Chang TT, Guan R, Tai DI et al. One-year trial of lamivudine for chronic hepatitis B. Asia Hepatitis Lamivudine Study Group. N Eng J Med 1998; 339: 61-68.

12. Angus P, Vaughan R, Xiong S, Yang H, Delaney W, Gibbs C et al. Resistance to adefovir dipivoxil therapy associated with the selection of a novel mutation in the HBV polymerase. Gastroenterology 2003; 125: 292-297.

13. Ilan Y, Nagler A, Adler R, Naparstek E, Or R, Slavin S et al. Adoptive transfer of immunity to hepatitis B virus after T cell-depleted allogeneic bone marrow transplantation. Hepatology 1993; 18: 246-252.

14. Shouval D, Adler R, Ilan Y. Adoptive transfer of immunity to hepatitis B virus in mice by bone marrow transplantation from immune donors. Hepatology 1993; 17: 955-959.

15. Ilan Y, Nagler A, Shouval D, Ackerstein A, Or R, Kapelushnik J et al. Development of antibodies to hepatitis B virus surface antigen in bone marrow transplant recipient following treatment with peripheral blood lymphocytes from immunized donors. Clin Exp Immunol 1994; 97: 299-302.

16. Ilan Y, Nagler A, Zeira R, Adler R, Slavin S, Shouval D. Maintenance of immune memory to the hepatitis B envelope protein following adoptive transfer of immunity in bone marrow transplant recipients. Bone Marrow Transpl 2000; 26: 633-638.

17. Ilan Y, Nagler A, Adler R, Tur-kaspa R, Slavin S, Shouval D. Ablation of persistent hepatitis B by bone marrow transplantation from a hepatitis B-immune donor. Gastroenterology 1993; 104: 1818-1821.

18. Lok A, Liang RH, Chung H. Recovery from chronic hepatitis B. Ann Intern Med 1992; 116: 957.

19. Lau GK, Lok AS, Liang RH, Lai CL, Chiu EK, Lau YL et al. Clearance of hepatitis B surface antigen after bone marrow transplantation: role of adoptive immunity transfer. Hepatology 1997; 25: 1497-1501.

20. Lau GK, Suri D, Liang RH, Rigopoulou EI, Thomas MG, Mullerova I et al. Resolution of chronic hepatitis B and anti-HBs seroconversion in humans by adoptive transfer of immunity to hepatitis B core antigen. Gastroenterology 2002; 122: 614-624.

21. Lau GKK, Liang R, Lee CK, Yuen ST, Hou J, Lim WL, Williams R. Clearance of persistent hepatitis B virus infection in Chinese bone marrow transplant recipients whose donors were anti-hepatitis B core- and anti-hepatitis B surface antibody-positive. J Infect Dis 1998;178:1585-91.

22. Caselitz M, Link H, Hein R, Mascheck H, Boker K, Poliwoda $\mathrm{H}$ et al. Hepatitis B associated liver failure following bone marrow transplantation. J Hepatol 1997; 27: 572-577.

23. Lo CM, Fung JT, Lau GK, Liu CL, Cheung ST, Lai CL et al. Development of antibody to hepatitis B surface antigen after liver transplantation for chronic hepatitis B. Hepatology 2003; 37: 36-43.

24. Gu YL, Dahmen U, Doebel L, Li J, Dirsch O, Polywka S et al. Influence of CsA treatment on adoptive transfer of immunity after allogeneic kidney transplantation in rats. Transpl Proc 2001; 33: 398-400.

25. Togashi H, Ohno S, Matsuo T, Watanabe H, Saito T, Shinzawa H, Takahashi T. Interferon-gamma, tumour necrosis factor-alpha and interleukin 1-beta suppress the replication of hepatitis B virus through oxidative stress. Res Commun Mol Pathol Pharmacol 2000; 107: 407417.

26. Gianotti N, Uberti-Foppa C, Boeri E, Marinelli M, Tambussi G, Finazzi R et al. Hepatitis B surface antigen clearance and appearance of antibodies against hepatitis B surface after treatment with recombinant interleukin 2 in human immunodeficiency virus-infected patients. Hepatology 2000; 32: 1409-1410.

27. Tilg H, Vogel W, Tratkiewicz J, Aulitzky WE, Herold M, Gruber M et al. Pilot study of natural human interleukin-2 in patients with chronic hepatitis B. Immunomodulatory and antiviral effects. J Hepatol 1993; 19: 259-267.

28. Thibault V, Delaugerre C, Calvez V, Costagliola D, Tubiana R, Katlama C. Interleukin 2 treatment does not modify hepatitis B or C replication in human immunodeficiency virus-infected patients: results from a randomized controlled trial. Hepatology 2002; 35: 238-239.

29. Artillo S, Pastore G, Alberti A, Milella M, Santantonio T, Fattovich G, et al. Double-blind, randomized controlled trial of interleukin-2 treatment of chronic hepatitis B. J Med Virol 1998; 54: 167-172. 
30. Bruch HR, Korn A, Klein H, Markus R, Malmus K, Baumgarten R et al. Treatment of chronic hepatitis B with interferon alpha2b and interleukin-2. J Hepatol 1993; 17: S52-S55.

31. Cavanaugh VJ, Guidotti LG, Chisari FV. Interleukin-12 inhibits hepatitis B virus replication in transgenic mice. J Virol 1997; 72: $3236-3243$.

32. Carreno V, Zeuzem S, Hopf U, Marcellin P, Cooksley WG, Fevery J et al. A phase I/II study of recombinant human interleukin-12 in patients with chronic hepatitis B. J Hepatol 2000; 32: 317-324.

33. Krastev Z, Jelev D, Antonov K, Alagozian V, Kotzev I. Chronic HBV infection: immunomodulation with levamisole in viremic HBeAg positive or anti-HBe positive patients- a pilot study. Hepatogastroenterology 1999; 46: 3184-3188.

34. Weiner HL. Oral tolerance: immune mechanisms and treatment of autoimmune diseases. Immunol Today 1997; 18: $335-343$.

35. Gotsman I, Beinart R, Alper R, Rabbani E, Engelhardt D, Ilan Y. Induction of oral tolerance towards hepatitis B envelope antigens in a murine model. Antiviral Res 2000; 48: 17-26.

36. Safadi R, Israeli E, Papo O, Shibolet O, Melhem A, Bloch A, et al. Treatment of chronic hepatitis B virus infection via oral immune regulation towards hepatitis B virus proteins. Am J Gastroenterol 2003; 98: 2505-2515.

37. Shuloff RA, Low TLK, Thurman GB, Goldstein AL. Thymosins and other hormones of the thymus gland. In: Sell K, ed. The Lymphocyte. New York: Liss, 1981: 191-215.

38. Low TLK, Goldstein AL. Thymosins: structure, function and therapeutic applications. Thymus 1984; 6: 27-43.

39. Chien RN, Liaw YF, Chen TC, Yeh CT, Sheen IS. Efficacy of thymosin $\alpha-1$ in patients with chronic type B hepatitis: a randomized controlled trial. Hepatology 1998; 27: 1383-1387.

40. Chan HL, Tang JL, Tam W, Sung JJ. The efficacy of thymosin in the treatment of chronic hepatitis B virus infection: a meta-analysis. Aliment Pharmacol Ther 2001; 15: 1899-1905.

41. Rasi G, Muthenick MG, Di Virgilio D, Sinibaldi-Vallebona P, Pierimarchi P, Collela F et al. Combination low-dose lymphoblastoid interferon and thymosin-alpha 1 therapy in the treatment of chronic hepatitis B. J Viral Hepatitis 1996; 3: 191-196.

42. Saruc M, Ozden N, Turkel N, Ayhan S, Hock LM, Tuzcuoglu I, Yuceyar H. Long-term outcomes of thymosin alpha 1 and interferon alpha 2b combination therapy in patients with hepatitis B e antigen negative chronic hepatitis B. Br J Pharm Sci 2003; 92: 1386-1395.

43. Lau GK, Nanji A, Hou J, Fong DT, Au WS, Yuen ST et al. Thymosin- $\alpha 1$ and famciclovir combination therapy activates T cell response in patients with chronic hepatitis B in immune tolerant phase. J Viral Hepatitis 2002; 9: 280-287.

44. Cooksley WG, Piratvisuth T, Lee SD, Mahachai V, Chao YC, Tanwandee T et al. Peginterferon alpha-2a (40kDa): an advance in the treatment of hepatitis B e antigen positive chronic hepatitis B. J Viral Hepatitis 2003; 10: 298-305.

45. Janssen HLA, Senturk H, Zeuzem S. Peginterferon alfa-2b and lamivudine combination therapy compared with peginterferon alfa-2b for chronic HBeAg-positive hepatitis B: A randomized, controlled trial in 307 patients. In: 54th Annual Meeting of the American Association for the Study of Liver Diseases Late-breaker session, Abstract 246A; October 24-28, 2003; Boston, MA.

46. Marcellin P, Lau GK, Bonino F, Fraci P, Hadziyannis S, Jin R et al. Peginterferon alfa-2a (40 kD) (PEGASYS) monotherapy is more effective than lamivudine monotherapy in the treatment of HBeAg-negative chronic hepatitis B: 72-week results from a phase III, partially doubl-blind study of PEGASYS alone vs. PEGASYS plus lamivudine vs. lamivudine. J Hepatolo 2004; 40 (S): 34.

47. Akbar SM, Kajino K, Tanimoto K, Kurose K, Masumoto T, Michitaka K et al. Placebo-controlled trial of vaccination with hepatitis B virus surface antigen in hepatitis B virus transgenic mice. Journal of Hepatology 1997; 26: 131-137.

48. Mancini M, Hadchouel M, Tiollais P, Pourcel C, Michel ML. Induction of anti-hepatitis B surface antigen (HBsAg) antibodies in HBsAg producing transgenic mice: possible way of circumventing 'nonresponse' to HBsAg. Journal of Medical Virology 1993; 39 : 67-74.

49. Pol S, Driss F, Michel ML, Nalpas B, Berthelot P, Brechot C. Specific vaccine therapy in chronic hepatitis B infection. Lancet $1994 ; 344: 342$.

50. Wen YM, Wu XH, Hu DC, Zhang QP, Guo SQ. Hepatitis B vaccine and anti-HBs complex as approach for vaccine therapy. Lancet 1995 ; 345: $1575-1576$.

51. Pol S, Nalpas B, Driss F, Michel ML, Tiollais P, Denis J et al. Efficacy and limitations of a specific immunotherapy in chronic hepatitis B. J Hepatology 2001; 34: 917-921.

52. Yalcin K, Acar M, Degertekin H. Specific hepatitis B vaccine therapy in inactive HBsAg carriers: a randomized controlled trial. Infection 2003; 31: 221-225.

53. Ren F, Hino K, Yamaguchi Y, Funatsuki K, Hayashi A, Ishiko H et al. Cytokine-dependent anti-viral role of CD4-positive T cells in therapeutic vaccination against chronic hepatitis B viral infection. J Med Virol 2003; 71: 376-384.

54. Heineman TC, Clements-Mann ML, Poland GA, Jacobson RM, Izu AE, Sakamoto D et. al. A randomized controlled study in adults of the immunogenicity of a novel hepatitis B vaccine containing MF59 adjuvant. Vaccine 1999; 17: 2769-2778.

55. Wright TL, Tong MJ, Hsu HH. Phase I study of a potent adjuvanted hepatitis B vaccine (HBV/MF59) for therapy of chronic hepatitis. Hepatology 1999; 30: 421A.

56. Davis HL. Use of CpG for enhancing specific immune responses. Current topics in Microbiology and Immunology 2000; 247: 171-183.

57. Heathcote J, McHutchison J, Lee S, Tong M, Benner K, Minuk G et al. A pilot study of the CY-1899 T-cell vaccine in subjects chronically infected with hepatitis B virus. The CY1899 T Cell Vaccine Study Group. Hepatology 1999; 30: 531-536.

58. Livingston BD, Crimi C, Grey H, Ishioka G, Chisari FV, Fikes J et al. The hepatitis B virus-specific CTL responses induced in humans by lipopeptide vaccination are comparable to those elicited by acute viral infection. J Immunol 1997; 159: 1383-1392.

59. Davis HL, Michel ML, Whalen RG. DNA-based immunization induces continuous secretion of hepatitis B surface antigen and high levels of circulating antibody. Human Molecular Genetics 1993; 2: 1847-1851.

60. Michel ML, Davis HL, Schleef M, Mancini M, Tiollais P, Whalen RG. DNA-mediated immunization to the hepatitis B surface antigen in mice: aspects of the humoral response mimic hepatitis B viral infection in humans. Proc Natl Aca Sci USA 1995; 92: 5307-5311.

61. Pancholi P, Lee DH, Liu Q, Tackney C, Taylor P, Perkus M et al. DNA prime/canarypox boost-based immunotherapy of chronic hepatitis B virus infection in a chimpanzee. Hepatology 2001; 33: 448-454.

62. Sallberg M, Hughes J, Javadian A, Ronlov G, Hultgren C, Townsend K et al. Genetic immunization of chimpanzees chronically infected with the hepatitis B virus using a recombinant retroviral vector encoding the hepatitis B virus core antigen. Human Gene Therapy 1998; 9: 17191729.

63. Roy MJ, Wu MS, Barr LJ, Fuller JT, Tussey LG, Speller S et al. Induction of antigen-specific CD8+ T cells T helper cells and protective levels of antibody in humans by particle-mediated administration of a hepatitis B virus DNA vaccine. Vaccine 2000; 19: $764-768$. 